\title{
FACTORS AFFECTING CROWDFUNDING INVESTOR NUMBER IN AGRICULTURAL PROJECTS: THE DUMMY REGRESSION MODEL
}

\author{
Yunita Siti Mardhiyyah"), Mohammad Arif Rasyidi**), and Lailatul Hidayah ${ }^{* * *}$ \\ *) Agroindustrial Technology Department, Universitas Internasional Semen Indonesia (UISI) \\ Jl. Veteran, Gresik, East Java, Indonesia 61122, Indonesia \\ **) Informatics Department, Universitas Internasional Semen Indonesia (UISI) \\ Jl. Veteran, Gresik, East Java, Indonesia 61122, Indonesia
}

\begin{abstract}
As an important sector in the Indonesian economy, the low capital problems in agriculture should be solved. Crowdfunding is one of the solutions gaining modal from society. This agricultural investment could be an attractive personal asset, too. But, no information yet about the complete characteristics of agricultural projects that fetching the people's participation to invest. Hence, the aim of this research is to find out the factors that influence people's participation in agricultural business investment with crowdfunding schemes. The quantitative data collected from 468 agricultural projects held by agricultural business startup PT. XYZ was analyzed. The six characteristics of the project are role as independents factors. They were project types (loans and profit sharing), project fields (agriculture, livestock, and fisheries), project risk (low, moderate, and high), project duration, the amount of capital needed and profit assumption. All the factors have been analyzed by a multiple regression model to estimate the number of investors. The results showed that the number of crowdfunding agriculture-based projects investor can be modeled by dummy regression. The longer project duration will decrease the number of investors by 0.577 people. The higher risk of the project will lower the number of investors. Based on the projects field, the most interesting projects are the livestock project, followed by agriculture and the last is the fisheries project. Overall, the project period, project risk and project field are the factors that influence people's participation in agricultural business investment with crowdfunding schemes. In the future, crowdfunding livestock projects with a short implementation period (around 3 months), and low risk can be sought so that more people participate in becoming investors.
\end{abstract}

Keywords: crowdfunding, agriculture project, agricultural investment, multiple regression model, dummy regression

\begin{abstract}
Abstrak: Pertanian adalah sektor penting dalam perekonomian Indonesia, permasalahan rendahnya modal di sektor pertanian harus diselesaikan. Crowdfunding merupakan sebagai salah satu solusi yang mengumpulkan dana dari masyarakat. Bisnis investasi pertanian ini sepatutnya menarik untuk dijadikan satu aset pribadi. Namun, tidak ada informasi terkait karakteristik yang lengkap dari proyek pertanian yang menarik partisipasi masyarakat untuk berinvestasi. Oleh karen itu, tujuan penelitian ini adalah untuk mengetahui faktor-faktor yang mempengaruhi partisipasi masyarakat dalam investasi bisnis pertanian dengan skema crowdfunding. Data kuantitatif yang diperoleh dari 468 bisnis pertanian yang dilaksanakan oleh bisnis startup PT. XYZ digunakan dalam penenlitian ini. Keenam faktor karakteristik proyek digunakan sebagai variabel independent, yaitu jenis proyek (pinjaman dan bagi-hasil), bidang proyek (pertanian, peternakan, dan perikanan), risiko proyek (rendah, sedang, dan tinggi), durasi proyek, jumlah modal yang dibutuhkan, dan asumsi laba. Semua faktor dianalisis menggunakan model regresi berganda untuk memperkirakan jumlah investor. Hasil penelitian menunjukkan bahwa jumlah investor proyek pertanian berbasis crowdfunding dapat dimodelkan dengan regresi dummy. Semakin lama durasi proyek, jumlah investor akan berkurang sebanyak 0.577 orang. Semakin tinggi risiko proyek maka jumlah investor akan semakin turun. Berdasarkan bidang proyek, proyek yang paling menarik adalah proyek peternakan, diikuti oleh pertanian dan terakhir adalah proyek perikanan. Secara keseluruhan, dapat disimpulkan bahwa faktor durasi proyek, resiko proyek dan jenis proyek adalah faktor-faktor yang mempengaruhi partisipasi masyarakat dalam investasi bisnis pertanian dengan skema crowdfunding. Ke depannya, proyek peternakan dengan periode implementasi yang singkat (sekitar 3 bulan), dan risiko rendah dapat diupayakan sehingga lebih banyak orang berpartisipasi menjadi investor.
\end{abstract}

Kata kunci: crowdfunding, proyek pertanian, investasi pertanian, model regresi berganda, regresi dummy

\footnotetext{
${ }^{1}$ Corresponding author:

Email: yunita.mardhiyyah@uisi.ac.id
} 


\section{INTRODUCTION}

Agriculture is the main sector driving the Indonesian economy. Data from the Central Statistics Agency (BPS) shows that $37.8 \%$ (48.42 million) of the Indonesian population work in the agricultural sector, it is larger than other business sectors (BPS, 2018). Agricultural sectors could be parties into several subsectors, for instance, crops, livestock, horticulture, fishery, and forestry (Rofiqi et al. 2018). The agriculture business is a complex economic project that involves various parties, requires large funds and has a high risk (Syuaib, 2016; Winarso, 2015). One of the agricultural problems complexity is low capital (Kusumah et al. 2018). This condition is not only happening in the production sector (farmers, fishermen, breeders) but also in the distributor side of the agriculture business. Loan funds or investments could be a solution to these problems (Saiti et al. 2018).

Given the importance of the agricultural sector, efforts to invest in agriculture began to be encouraged. Providers of agricultural investment services can be banks, cooperatives, and even individuals (Supanggih and Widodo, 2013). According to (Indonesian Bank) BI data, up to 2016, it was recorded that the distribution of credit financing in the agricultural sector only reached 212.4 trillion IDR or $5.7 \%$ of total bank loans of 2,721.9 trillion IDR (Baskoro et al. 2017). The number of agricultural cooperatives engaged in capital loan services is also limited.

On the other hand, the development of the digital era which was marked by the increasing use of computers and the internet (Industrial Revolution 4.0) had the effect of changing lives. The society began to be very literate in the internet world and take advantage of the existence of the internet in all its activities, including in terms of financial investments in agriculture. One of the digital-based financial investments is known as crowdfunding. Crowdfunding is a funding technique for projects or business units that involve the community at large numbers (Filimonova et al. 2018). Crowdfunding is important in agriculture, considering that agricultural activities will not be carried out without enough capital. It was also reported that investment is a need in agriculture to support its high productivity (Saiti et al. 2018; Yan et al. 2018).
Development of information technology in agriculture produced many agricultural e-commerce (Ardiansyah, 2019; Rahmawati et al. 2018), and also the agricultural e-investments or online crowdfunding. Currently, there are various agricultural business startup sites or agricultural e-investment that have been developed in Indonesia. They are I-grow (https://www. igrow.asia/), Vestifarm ${ }^{\circledR}$ (https://vestifarm.com/) or Crowde ${ }^{\circledR}$ (https://crowde.co/), etc. They perform Peer to Peer (P2P) Lending platform for agricultural capital. P2P lending system allows farmers to apply for loans on platforms/sites/marketplaces online, which then investors (individuals) can also choose suitable agricultural projects to be capitalized through electronic systems with internet networks. These startups have started to be developed 10 years ago and are growing until now. The provision of online crowdfunding sites has also encouraged all levels of society to participate in agricultural investments (Anggita, 2013). This interesting trait of agricultural business investment within online crowdfunding motivates the research question: What are the factors that influence people's participation in investing in agricultural business with crowdfunding schemes?

Research on the agriculture sector is always been a hot issue in the world (especially in Indonesia as an agricultural country), so does the online or internet of thing issues. In Russia, crowdfunding has to be a promising tool to raise the finance of innovative and investment projects in agriculture (Filimonova et al. 2018). It was stated that in 2014, the backers in the crowdfunding website (Boomstarter) pledged about $2 \%$ of the agricultural project and grew up to $4 \%$ in 2015 , with total modal of platform increasing as well (RUB 53,251,515 up to RUB 91,134,989). Filimonova et al. (2018) also studied that the social effect of the project, project scale (financial needs), profitability and a payback period of project are criteria for choosing a crowdfunding strategy as part of project finance in agriculture.

In addition, as a developing country, Afghanistan has also proposed a salam-based crowdfunding structure for financing agricultural activities (Saiti et al. 2018). The study has identified some advantages by offering salam-based crowdfunding, Islamic banking, and finance. As an Islamic country, Indonesia might also develop Shari'ah based crowdfunding scheme. In the type of sharia crowdfunding, it shows that knowledge, trust, and technology have a positive effect on people's 
motivation to invest in using a sharia crowdfunding scheme (Chairunisa, 2018). Sharia schemes are filled generally like profit-sharing schemes that divide profits or losses in proportion.

Recently some studies were carried out crowdfunding topics and agriculture projects in Indonesia. It was analyzed that crowdfunding management that held by Crowde (one of Indonesian crowdfunding platform) gained positive response from the farmers (Avisha et al. 2019). As a key partner, most of the partner farmers say the process or procedure of the capital scheme is very easy to follow. They also judge that the crowdfunding model is very useful and suitable as access to farmers' capital.

In contradiction, only of few published papers study about crowdfunding and agricultural project in a quantitative approach. The previous study only showed the correlation of the social effect of the project, project scale (financial needs), profitability and a payback period of the project (Filimonova et al. 2018), but no study yet that could describe the correlation of risk and project fields. There are five subsectors of agriculture that show significant characteristics. The previous study also only focusing the crowdfunding in sharia or shared based project types (Chairunisa, 2018; Saiti et al. 2018). Moreover, many crowdfunding projects still employ loan project types. Hence, this paper seeks to make the first few steps towards a quantitative study of agricultural project crowdfunding with complete factors (the project types, project fields, project risk, project duration, the amount of capital needed and profit assumption on the number of investors).

This paper contributes to the theoretical system and research ideas of agricultural research. On one hand, this paper enriches the existing theoretical research of crowdfunding research in agriculture, makes an innovative investigation into the complex factors that influencing people's participation in investing in agricultural business with crowdfunding schemes, and finds a certain number of predicted investors in the crowdfunding projects by using a model. On the other hand, from the aspect of research ideas, this paper uses an innovative model solution by multiple regression with the addition of a dummy regression method to carry out the research result. Furthermore, this information will help farmers or the managerial of a crowdfunding platform to provide the projects that are interesting to the community.

\section{METHODS}

Data for this study were acquired from PT. XYZ as one of a crowdfunding platform. The data taken is quantitative with time series from 2015 to 2018. Of those (468 projects), 248 are loan crowdfunding scheme and 220 are profit-sharing schemes. Table 1 presents a summary of data characteristics. PT. XYZ was selected based on some reasons: (1) It was performing crowdfunding for many agricultural projects since 2015 and authorized by OJK (Otoritas Jasa Keuangan; Indonesian Financial Service Authority); (2) The total farmers that being partner is 5,071 person that spread among 276 villages; (3) and of course, only PT. XYZ that informs complete information of project characteristics to the public.

\section{Variable Declaration}

Dependent variable (The dependent variable in this paper is the number of crowdfunding investors). Independent or explanatory variables (There are two kinds of explanatory variables. The first variable group consists of project duration, the amount of capital needed and profit assumption, which is scale type data. And the second variable group consists of project types, project fields and project risk, which are nominal type data that needed to convert into dummy variables).

The dummy variable is a numerical variable used in regression analysis to represent subgroups of the sample in the study. In research design, a dummy variable is adopted to distinguish different treatment groups. In the simplest case, there is a 0,1 dummy variable where a subject is given a value of 0 if they are the reference group or a 1 if they are in the group of interest.

This paper, first, whether the project is applied the fixed interest for a certain time as the returned modal, this is categorized as the loan project type. Thus, this variable is assigned as 1. Otherwise (profit-sharing type project), it is assigned as 0 , to generate a dummy variable of project type. 
Table 1. Summary of agricultural based projects characteristics

\begin{tabular}{lcccc}
\hline \multicolumn{1}{c}{ Projects } & Number of Projects & $\begin{array}{c}\text { Average of Capital } \\
\text { amount (IDR) }\end{array}$ & $\begin{array}{c}\text { Average of Project } \\
\text { duration (day) }\end{array}$ & $\begin{array}{c}\text { Average of Profit } \\
\text { Assumption (\%) }\end{array}$ \\
\hline Loan & 248 & $30,921,613$ & 63 & 3.0 \\
Agriculture & 189 & $31,340,952$ & 47 & 2.1 \\
High & 4 & $52,610,500$ & 165 & 9.3 \\
Low & 156 & $31,739,112$ & 39 & 1.6 \\
Moderate & 29 & $26,265,393$ & 76 & 3.7 \\
Fishery & 25 & $35,614,764$ & 68 & 3.2 \\
High & 2 & $18,500,000$ & 95 & 9.1 \\
Low & 13 & $35,075,336$ & 69 & 3.3 \\
Moderate & 10 & $39,738,973$ & 62 & 2.0 \\
Livestock & 34 & $25,139,735$ & 148 & 7.7 \\
High & 1 & $100,000,000$ & 180 & 10.0 \\
Low & 30 & $19,589,800$ & 152 & 7.9 \\
Moderate & 3 & $55,685,667$ & 103 & 5.5 \\
Profit-sharing & 220 & $21,373,269$ & 139 & 6.5 \\
Agriculture & 117 & $21,210,886$ & 149 & 7.3 \\
High & 60 & $16,400,170$ & 174 & 6.4 \\
Low & 7 & $87,930,000$ & 51 & 1.9 \\
Moderate & 50 & $17,643,069$ & 133 & 9.0 \\
Fishery & 39 & $14,211,194$ & 147 & 6.1 \\
High & 24 & $15,216,958$ & 158 & 6.9 \\
Moderate & 15 & $12,601,971$ & 130 & 4.7 \\
Livestock & 64 & $26,034,517$ & 116 & 5.5 \\
High & 1 & $20,000,000$ & 90 & 4.6 \\
Low & 7 & $23,705,000$ & 90 & 4.6 \\
Moderate & 56 & $26,433,466$ & 120 & 5.6 \\
Total & 468 & $26,433,075$ & 99 & \\
\hline & & & & .7 \\
\hline
\end{tabular}

As for the project field, although agriculture sectors could be divided into 5 subsectors (crops, livestock, horticulture, fishery, and forestry), in this research, there are only three categories. Agriculture project consists of crops, horticulture and forestry project field that deals with any business activities that have the plant-based product. Thus, other project fields are livestock and fishery. The livestock project consists of any business activities from farm to fork that having a deal with the animal (cattle, poultry, goat, sheep, etc.). Thus, the fisheries project field consists of any project that having a relationship with raising or harvesting fish.

The three of the projects (agriculture, fisheries, and livestock) are nominal data, hence there will be two dummy models on the project field. First is the fisheries field as the group of interest. Whether the fisheries project is assigned as 1 and the other projects are assigned as 0 . Second is the livestock field as the group of interest. Whether livestock project is assigned as 1 and others are assigned as 0 .

At last, they are three kinds of project risk (low, moderate, and high) that also analyzed in dummy variables. First, moderate and low risk is analyzed where the moderate risk project is assigned as 1 and the latter is assigned as 0 . Second, a high and low-risk project where the high-risk project is assigned as 1 and the later is assigned as 0 .

The analytical tool used to analyze the data is multiple linear regression, where the dependent variable $\mathrm{Y}$ (number of investors) can depend on two or more independent variables. The independent variables consist of scale type data (amount of capital needed, and assumptions of profit) and nominal type data (a type of project, type of crowdfunding, length of the 
project). For qualitative data, researchers used the dummy method (D) to see the effect on the dependent variable.

The regression function used is as follows:

$$
\begin{aligned}
\mathrm{y}= & \mathrm{b}_{0}+\mathrm{a}_{1.1} \mathrm{D}_{1.1}+\mathrm{a}_{2.1} \mathrm{D}_{2.1}+\mathrm{a}_{2.2} \mathrm{D}_{2.2}+\mathrm{a}_{3.1} \mathrm{D}_{3.1}+\mathrm{a}_{3.2} \mathrm{D}_{3.2}+ \\
& \mathrm{a}_{4.0} \mathrm{X}_{4.0}+\mathrm{a}_{5.0} \mathrm{X}_{5.0}+\mathrm{a}_{6.0} \mathrm{X}_{6.0} \text { (Equation 1) }
\end{aligned}
$$

Where: y (Number of crowdfunding investors); $b_{0}$ (constants); $\mathrm{a}_{1.1}$ (The coefficient of the type of loan project); $\mathrm{a}_{2.1}$ (Coefficient of the fisheries project field); $a_{2.2}$ (Coefficient on the field of livestock projects); $a_{3.1}$ (Project risk coefficient moderate); $a_{3.2}$ (High project risk coefficient); $a_{4.0}$ (Project duration coefficient); $a_{5.0}$ (The coefficient of the amount of capital required); $\mathrm{a}_{6.0}$ (The coefficient of profit assumption); $\mathrm{D}_{1.1}$ (Type of loan project); $\mathrm{D}_{2.1}$ (Field of fisheries project); $\mathrm{D}_{2.2}$ (Field of livestock projects); $\mathrm{D}_{3.1}$ (Moderate project risk); $\mathrm{D}_{3.2}$ (High projects risk); $\mathrm{X}_{4.0}$ (Project duration in days); $\mathrm{X}_{5.0}$ (Amount of capital required in IDR); $\mathrm{X}_{6.0}$ (Assume profit in percent).

This study also carried out several statistical tests before the multiple regression equation was determined. This test is also called the classical assumption which consists of a normality test, multicollinearity test, and heteroscedasticity test, test coefficient of determination, t-test, and $\mathrm{F}$ test (ANOVA). All data analysis was carried out using SPSS software.
For obtaining the answer to this research question, the development of a multiple regression model from six independents factors could be an alternative. They were project types (loans and profit sharing), project fields (agriculture, livestock, and fisheries), project risk (low, moderate, and high), project duration, the amount of capital needed and profit assumption. Do those factors influence people's participation in investing in agricultural business with crowdfunding schemes? The hypothesis declared below:

H0: There is no significant effect of project types (loans and profit sharing), project fields (agriculture, livestock, and fisheries), project risk (low, moderate, and high), project duration, the amount of capital needed and profit assumption on the people's participation in investing in agricultural business with crowdfunding schemes.

H1: Project types (loans and profit sharing), project fields (agriculture, livestock, and fisheries), project risk (low, moderate, and high), project duration, the amount of capital needed and profit assumption has significant on the people's participation in investing in agricultural business with crowdfunding schemes.

Figure 1 presents the logical framework of the research. The characteristics of the project might be the factor that influences the decision of the person (prepositive investor) whether to invest or not.

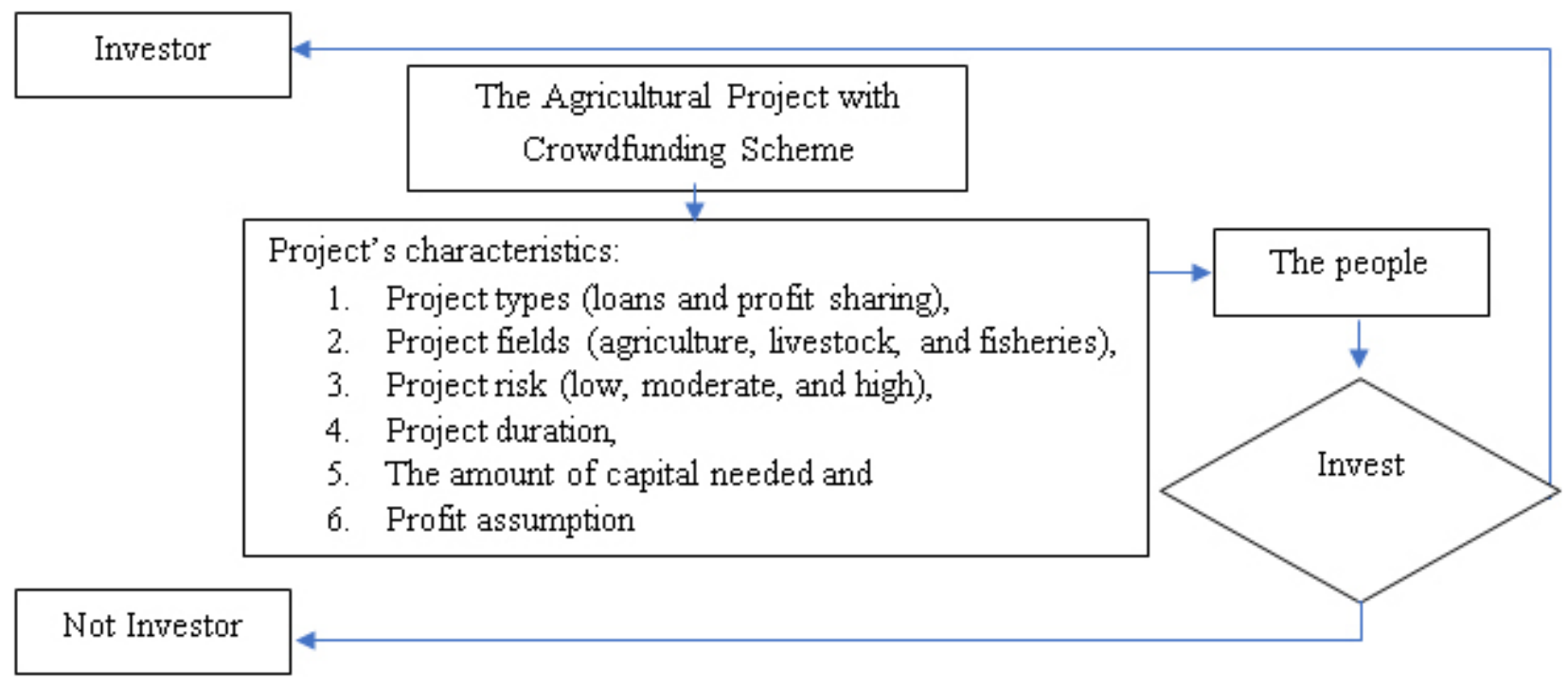

Figure 1. Logical framework of the research 


\section{RESULTS}

\section{The Classical Assumption}

The classical assumption was determined in this research from data. The normality test is used to see whether the residual value of a regression model is normally distributed or not. A good regression model is a model that has a residual value that is normally distributed. The results of the normality test with the Normal P-P plot show a data plot approaching the line so that data in the regression model can be said to be normally distributed. This normality test also shows the data with a normal curve histogram. Figure 2 depicts that the research data forms a normal condition and most of the bars are under the curve, so the variables can be said to be normally distributed.

Agooddatahas noheteroscedasticity. Heteroscedasticity shows the inequality of variants from residuals for all observations in the linear regression model. The result of its test is shown in Figure 3. Based on the Scatterplot in Figure 3, it is known that: (1)Data points spread above and below or around the number 0, (2)Data points do not gather just above or below, (3)The spread of data points does not form a wavy pattern widening then narrows and widens again, and (4)Distribution of non-patterned data points. So, it can be concluded that there is no heteroscedasticity problem, and a good and ideal regression model can be fulfilled.

Other tests that should be needed are multicollinearity test. The result of the test can be seen in Table 2. The Multicollinearity Test is used to see whether there is a correlation between the independent variables. Based on Table 2, the value of VIF (Variance Proportions) on all independent variables is less than 10 and the tolerance value is greater than 0.1 so that conclusions do not occur multicollinearity.

\section{The Regression Model}

The result of the regression linear model and t-test is shown in Table 3. The t-test is conducted to determine the significance of the effect of individual independent variables on the dependent variable. In Table 3 the factors that give a significant value at $\alpha(0.05)$ are duration, project risk and field/type of project. Other dependent factors, such as capital requirements, expected profit and type of project turned out to show insignificant value.
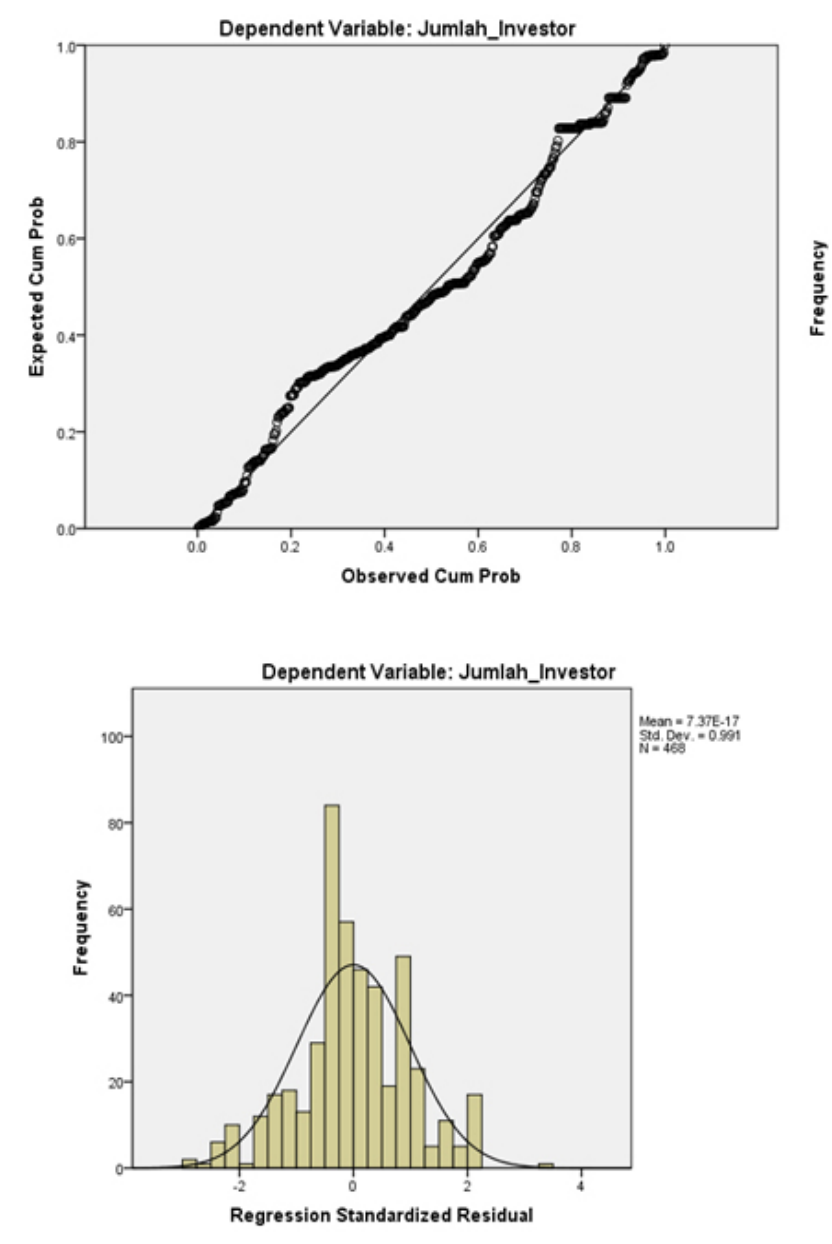

Figure 2. (a) Normal P-P plot data (b) Normal curve histogram from data

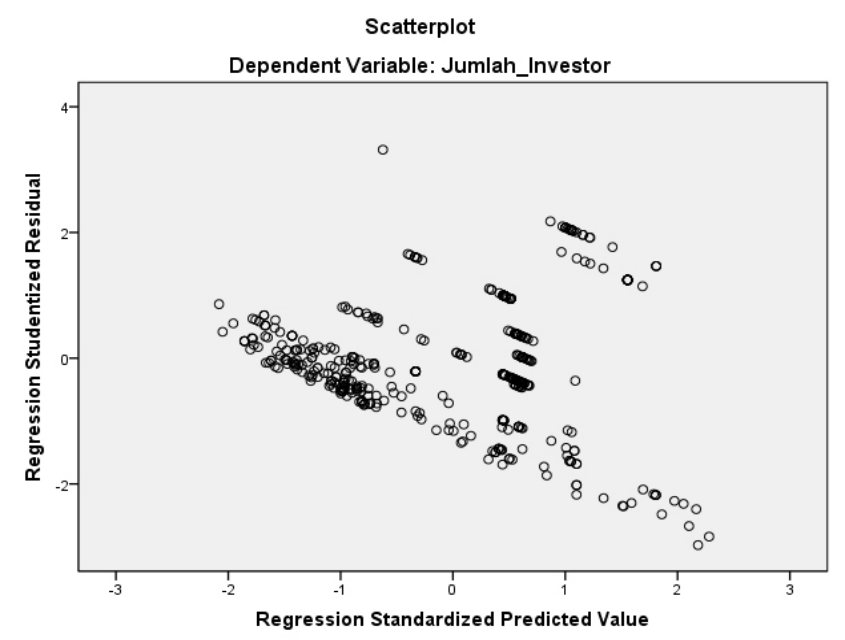

Figure 3. Heteroscedasticity scatterplot 
Table 2. Collinearity Diagnostics ${ }^{\mathrm{a}}$

\begin{tabular}{llcc}
\hline \multirow{2}{*}{ Model } & \multicolumn{2}{c}{ Collinearity Statistics } \\
\cline { 2 - 3 } & Tolerance & VIF \\
\hline $1 \quad$ (Constant) & & \\
& Type of loan project & .393 & 2.545 \\
& Field of fisheries project & .903 & 1.107 \\
& Field of fisheries project & .746 & 1.341 \\
& Project risk moderate & .445 & 2.246 \\
Risk of high projects & .329 & 3.041 \\
& Project duration & .508 & 1.970 \\
Amount of capital required & .960 & 1.042 \\
Assume profit & .845 & 1.183 \\
\hline
\end{tabular}

a. Dependent Variable: Number_of_Investor

The six independent variables are expected to influence the number of investor participation in crowdfundingbased agricultural project funding. Based on Table 3, the linear regression equation obtained to determine the number of investors is:

$$
\begin{aligned}
\mathrm{y}= & 292.3+116.6 \mathrm{D}_{1.1}-68.4 \mathrm{D}_{2.1}+217.8 \mathrm{D}_{2.2}- \\
& 102.4 \mathrm{D}_{3.1}-127.6 \mathrm{D}_{3.2}-0.58 \mathrm{X}_{4.0}+3.8 \times 10^{-7} \mathrm{X}_{5.0} \\
& +0.24 \mathrm{X}_{6.0}(\text { Equation } 2)
\end{aligned}
$$

Where: y (Number of crowdfunding investors in person); $\mathrm{D}_{1.1}$ (Type of loan project (profit sharing $=0$, loans $=1$ )); $\mathrm{D}_{2.1}$ (Field of fisheries project (agriculture $=0$, fishery $=1$, livestock $=0)$ ); $\mathrm{D}_{2.2}$ (Field of livestock projects (agriculture $=0$, fisheries $=0$, livestock $=1$ )); $\mathrm{D}_{3.1}$ (Project risk moderate $($ low $=0$, moderate $=1$, high $=0)$ ); $\mathrm{D}_{3.2}$ (Risk of high projects (low $=0$, moderate $=0$, high $=1)) ; X_{4.0}$ (Project duration in days); $X_{5.0}$ (Amount of capital required in IDR); $X_{6.0}$ (Assume profit in percent).

The model thus followed by Determination Coefficient Test (model summary), and ANOVA test. The test results of the coefficient of determination in Table 4 show that the variable Number of investors can only be explained by an independent variable of $36.0 \%$, while several $64.0 \%$ is explained by other variables outside of this study.

Further analysis was done by F-Test or ANOVA (Table $5)$. The $\mathrm{F}$ test is conducted to determine the significance of the effect of simultaneous independent variables on the dependent variable. Based on the ANOVA table it was found that there was a positive and significant influence between the independent variables on the dependent variable because the $\mathrm{F}$ level of significance was smaller than $\alpha(0.05)$.

\section{Factors Affecting the Investor Number}

Project type

In project type variables, data is processed using dummy data (D1.1). Equation 2 shows that the type of loan project will have 16 investors more than the profit-sharing project type. Unfortunately, the type of loan project is not a significant factor (Table 3). This loan system applies the principle of investment from investors in a certain amount that will be returned by giving fixed interest for a certain time. As for the profit-sharing system, the amount of capital provided will be returned with profits shared between farmers, financiers, and intermediaries. The amount of profitsharing percentage applied also varies depending on the agreement.Currently, many crowdfunding capitalization schemes are sharia-compliant (Chairunisa, 2018; Mufli, 2017; Tutuko et al. 2019) that have a similar concept as profit sharing.

This research could not prove the hypothesis that different project types would have a significant effect on the total investor. It might be caused by the unacknowledgment of crowdfunding types. The previous study by Filimonova et al. (2018), showed the social effect of the project, project scale (financial needs), profitability and payback period of projects are the critical factors in choosing the crowdfunding projects. Currently, the Financial Services Authority (OJK) in Indonesia has grouped crowdfunding schemes into 4 types, namely equity-based crowdfunding (capitalbased crowdfunding/share ownership), lending based crowdfunding (credit/debt-based crowdfunding), reward-based crowdfunding (prize-based crowdfunding), and donation-based crowdfunding (donation-based) (Serfiyani, 2018).

\section{Project Field}

Project sector variables, which consist of agriculture, livestock and fisheries also show significant value (Table 3). The field of research is also nominal data so that analysis is carried out with two dummy data (D2.1 and D2.2). The agricultural field is used as the basis for the equation. Based on Equation 2, fisheries projects have a lower number of investors than agriculture project around 68 people. The livestock sector has a higher number of investors than the agricultural sector with 217 people. 
Table 3. Coefficients of Regression Model ${ }^{\mathrm{a}}$

\begin{tabular}{|c|c|c|c|c|c|c|}
\hline & \multirow{2}{*}{ Model } & \multicolumn{2}{|c|}{$\begin{array}{l}\text { Unstandardized } \\
\text { Coefficients }\end{array}$} & \multirow{2}{*}{$\begin{array}{c}\text { Standardized } \\
\text { Coefficients } \\
\text { Beta } \\
\end{array}$} & \multirow[b]{2}{*}{$\mathrm{t}$} & \multirow[b]{2}{*}{ Sig } \\
\hline & & $\mathrm{B}$ & Std. Error & & & \\
\hline \multirow[t]{9}{*}{1} & (Constant) & 292.334 & 30.841 & & 9.479 & .000 \\
\hline & Type of loan project & 16.558 & 25.232 & .039 & .656 & .512 \\
\hline & Field of fisheries project & -68.451 & 24.175 & -.110 & -2.831 & .005 \\
\hline & Field of livestock project & 217.855 & 22.468 & .416 & 9.696 & .000 \\
\hline & Project risk moderate & -102.408 & 24.831 & -.229 & -4.124 & .000 \\
\hline & Risk of high projects & -127.608 & 34.641 & -.238 & -3.684 & .000 \\
\hline & Project duration & -.577 & .162 & -.185 & -3.558 & .000 \\
\hline & Amount of capital required & $3.860 \mathrm{E}-7$ & .000 & .053 & 1.402 & .162 \\
\hline & Assume profit & .238 & 1.291 & .007 & .184 & .854 \\
\hline
\end{tabular}

a. Dependent Variable: Number of the Investor

Table 4. Model Summary

\begin{tabular}{cccccc}
\hline Model & R & R Square & Adjusted R Square & Std. Error of the Estimate & Durbin-Watson \\
\hline 1 & $.609^{\mathrm{a}}$ & .371 & .360 & 170.78344 & 1.707 \\
\hline
\end{tabular}

a Predictors: (Constant), Type of loan project, Field of fisheries project, Field of livestock projects, Project risk moderate, Risk of high projects, Project duration, Amount of capital required, Assume profit; ${ }^{b}$ Dependent Variable: Number_of_investor

Table 5. ANOVA

\begin{tabular}{clccccc}
\hline & Model & Sum of Squares & df & Mean Square & F & Sig. \\
\hline \multirow{2}{*}{1} & Regression & 7894548.169 & 8 & 986818.521 & 33.833 & $.000 \mathrm{a}$ \\
& Residual & 13387644.812 & 459 & 29166.982 & & \\
& Total & 21282192.981 & 467 & & & \\
\hline
\end{tabular}

a Predictors: (Constant), Type of loan project, Field of fisheries project, Field of livestock projects, Project risk moderate, Risk of high projects, Project duration, Amount of capital required, Assume profit; ${ }^{b}$ Dependent Variable: Number_of_investor

Agricultural projects proposed on the P2P Lending website " $\mathrm{X}$ " include farming or cultivation, as well as trading or distribution of agricultural products. The agricultural sector is still the favorite of crowdfunding projects because of the needs and availability of resources in the field. The agricultural products are cereals (corn, rice), fruits (tomatoes, cucumber), vegetables (cabbage, cabbage, chili, lettuce, and other green vegetables), mushrooms, even forestry product. The fishery project is dominated by freshwater cultivation including catfish, pomfret, tilapia, pangasius, mas, and shrimp. Several other fishery projects such as crab fishermen and seafood product distribution were also found. While for livestock projects, it includes breeding of cattle, goat, sheep, and poultries (chickens and ducks, both for eggs and meat), as well as trading/ distribution.
The agricultural project still dominates from 468 types of projects managed, which is $65.4 \%$. Livestock projects occupy the second dominance $(20.9 \%)$ and the last is fisheries (13.7\%). The dominant number of agricultural projects is in line with the livelihoods of the Indonesian people, who are indeed dominant as farmers. This also shows that enthusiasts of agricultural projects are more dominant. The dominance of agricultural projects is also due to the high market demand related to agricultural products (rice, corn, vegetables, and fruit) compared to fishery products and or livestock. In fulfilling food needs, fisheries and livestock products are generally only used as side dishes and consumed in small quantities. It is different from rice which is the staple food of the Indonesian people, and is consumed in high quantities so it is necessary to ensure that supply is always there (so that many rice-based agricultural projects emerge). 
Although in quantity the number of agricultural projects is more than that of livestock projects, for each type of project, the number investor in livestock project is plus 217 people compared to agricultural projects (Equation $2)$. It is because the project requires a larger capital investment so that the number of investors who reduce funds is more.

\section{Project risk}

The next variable that is significant is project risk (Table 3). Project risk assessment is carried out by farm business startup managers. Indicators of the high and low risk of each project can be measured by several factors, such as weather, pest disease, harvest time, and rating from the farmer itself. The more factors that are found on a project, the higher the risk involved. Conversely, the fewer factors contained in a project, the less risk involved. It is in line with previous research, that knowledge is important in investment.

Based on Equation 2, the higher the risk (low $<$ moderate $<$ high), the less the number of investors, which is indicated by a negative sign (-) on the coefficient. With low risk as to the baseline, moderate risk has 102 investors, which are lower than the low-risk project. As for the high-risk project, the number of investors is 127 people lower than low-risk project.

Overall the projects implemented are $45.5 \%$ at low risk, $34.8 \%$ at moderate risk, and $19.7 \%$ at high risk. In the fisheries sector projects with moderate and high risk are the two dominant groups. As for the livestock sector, $60.2 \%$ is a medium risk project. In agriculture, $53.3 \%$ of the projects are categorized as low risk. It might be caused that the cultivation or trading of the plants or the project activities has a little obstacle. While the fisheries and livestock activities are having a higher risk than agriculture, it was caused by more factors are being involved (pest diseases, long time harvesting, etc.).

Based on the different types of projects (loans and profit sharing), it was found that on the loan project $80 \%$ had a low risk, while for the profit-sharing project a $55 \%$ risk was moderate and $39 \%$ high risk. Although no detail information was given by the PT. XYZ management about each project risk, but almost all the proposed investors have the same though to play safe. It was also stated that e-agribusiness is still new and rare activities in Indonesia. Therefore the management of the company needs to develop the strategy to enhance the customers and survive in the industry (Rahmawati et al. 2018).

\section{Project Duration}

It is very concerning to pay attention to the project duration before deciding to invest in an agriculturebased project. The duration variable coefficient shows the value of -0.57 which means, the longer the time the research project is implemented, the more the number of investors will be less than 0.577 times (Table $3)$. In general, all projects have an average project implementation time of around 99 days or 3 months. If it is divided more specifically per project type, on projects with a loan scheme, the average duration of the project is 63 days or 2 months. As for the profitsharing scheme, an average of 139 days or 5 months is obtained. It was in line with previous research (Filimonova, Ozerova, and Ermakova 2018). Based on the type of investment division, agriculture investment can be classified as a short-term investment, because the time is less than 1 year.

The current globalization and investment trends are now spreading in Indonesian society. In the current market, this short-term investment can be made in the form of deposits, bank certificates, or securities, namely shares. However, not everyone understands and knows banking investment. Therefore, crowdfunding-based investment can be an alternative. More emergence of start-up agricultural business, which is a Peer to Peer ( $\mathrm{P} 2 \mathrm{P})$ platform lending for agricultural capital is evidence of increasing public interest in this type of investment.

\section{Capital needed by the project}

The last two variables, the amount of capital needed, and the assumption of profit did not have a significant effect on social participation to provide crowdfunding financing (Table 3). The more capital needed; the number of investors will only increase by $3.86 \times 10-7$ from total capital. The variable coefficient is very small because generally the capital needed in the project also tends to be large. This research information is in line with the previous study (Filimonova, Ozerova, and Ermakova 2018). 
Although capital is positively correlated with the number of investors, the effect is not significant. The results of this study are different from the results of the (Vulkan, Åstebro, and Fernandez 2016) and (Lukkarinen et al. 2016) study which stated that the amount of capital from crowdfunding projects gave a positive interest in crowdfunding success and was a major factor.

On average, the capital of this agriculture-based project is 26 million IDR (Table 1). By grouping, loan projects generally require capital of 30 million, while in profit sharing projects it is only around 21 million. Whereas in the fields of fisheries, agriculture, and livestock, capital requires 24 million, 26 million and 25 million respectively. Almost the average value of capital requirements also causes capital not to have a significant effect on community participation in investing. It was supported by Wati \& Winarno (2018)'s research. They found that the success of crowdfunding funding for SME capital was influenced by the size of project capital, the number of investors, the minimum amount of investment, and the duration of the project.

\section{Amount of profit assumptions}

The assumption of profit also does not provide a significant factor (Table 3). Every one percent increase in profit assumed by the project owner, the number of investors who provide capital increased by 0.238 times. The assumed profit is $4.6 \%$ on average. In the type of loan project, generally, the maximum profit is $10 \%$, and an average of $3 \%$. Whereas in the profit-sharing project, a very varied profit is generated, ranging from $0 \%$ to $65 \%$ with an average of $6.5 \%$. Whereas in the field of fisheries, agriculture and animal husbandry the assumed profits are $4.66 \%, 4.68 \%$, and $6.00 \%$ respectively. The profit value that is not different from the field and/or type of project is also the cause of not the significant variation of profit on the number of investors.

The classic assumption test shows that the model obtained is quite feasible. As for the value of R2, it only shows a value of 0.36 (Table 4). Although this research already conducted the 6 variables as the independence factor that influence community participation in crowdfunding agriculture-based project funding, the information is still needed more exploration.

\section{Managerial Implications}

Based on the result in this paper, the factor that influences the people's participation in investing in agricultural business with crowdfunding schemes is project duration, project risk and project fields. Kind of project types or scheme (loan and profit-sharing) assume profit and amount of capital needed have no effect significantly on the number of investors.

The number of investors is an important variable in determining whether the crowdfunding funding project is desirable or not. Thus, the fund of desirable projects will immediately be met. If a project is launched without any interest from potential investors, farmers will not be able to immediately carry out their modal and do the agricultural activities on the land. The delay in fulfilling the number of funds, in addition, will impact to previous investors who have invested capital. They may feel unsure even this project has the potential to succeed or not. Meanwhile, if the fulfillment of capital is then fulfilled, but it is longer than the project implementation target, then in some cases, the agricultural project will still not be carried out (because of seasonal change factors, in the example). Furthermore, if the investor has already invested capital and then the funded project is said to be not running so that the money is returned and even losers, then it will certainly give a bad impression. Hence, the possibility of the investor not to fund again can be high.

Based on the equation obtained from this study, it is suggested that the managerial company of PT. XYZ has to find and finance projects that have crowdfunding projects with a short implementation period (around 3 months) with low risk and in the field of animal husbandry (livestock). Those characteristics are the investor's favorite. Whereas if among the three parameters are made priorities then what must be attempted is a short time, low risk of the project and then the project type of livestock.

Dissemination of information related to project characteristics that interested in consumers can be input for company management to be able to increase the participation of Indonesian people to invest in agriculture through the Crowdfunding scheme. In addition, besides getting as many potential new investors, the management also needs to provide after service to investors who have already invested capital. 
Providing updates on project progress information that sent to investors (via e-mail, for example) can be a guarantee to investors that funds that have been lent through this crowdfunding scheme are used properly. If possible, investors can also be included in project funded activities, for example at harvest time. So, the bounding between investors and management becomes strong and investors will be loyal and want to invest money again.

On the other hand, managers also need to educate and establish good relations with farmer partners. For farmers whose projects are funded, it is also necessary to help, especially in ensuring the financial process in the project is clear. As for the technical factors in the field and cultivation, the management does not need to interfere.

In addition to improving the quality of projects offered through the proper selection, marketing also still needs to do promotions related to the benefits of investment through crowdfunding schemes in agriculture. Points of social excellence and economic benefits could be more announced. Going forward, increasing the interest in agricultural investment through crowdfunding schemes can also increase agricultural productivity, help farmers getting ease capital and distinctly help to increase the welfare of Indonesian farmers.

\section{CONCLUSIONS AND RECOMMENDATIONS}

\section{Conclusions}

The results showed that the number of crowdfunding agriculture-based projects investor can be modeled by dummy regression. The six independent variables are project types (loans and profit sharing), project fields (agriculture, livestock, and fisheries), project risk (low, moderate, and high), project duration, the amount of capital needed by the project and the assumption of project profit. Significant influential variables are the project field, project risk, and duration of the project. The longer the project, the number of investors will decrease by 0.577 people. The higher the risk of the project, the lower the number of investors. The types of projects that are most in-demand are livestock continued agriculture and the last is fisheries. Overall, the project period, project risk and project field are the factors that influence people's participation in agricultural business investment with crowdfunding schemes. In the future, crowdfunding projects with a short implementation period (around 3 months) with low risk and in the field of animal husbandry (livestock) can be sought so that more people participate in becoming investors.

\section{Recommendations}

The six characteristics of the projects are still not enough parameters to explain the factors that influence people's participation in investing in agricultural business with crowdfunding schemes. Therefore, future research can be considered to add other aspects, including the minimum value of the investment, duration of funding, farmer quality, etc. Meanwhile, the suggestion for companies is marketing the projects by giving an example of a success story of investment. This story will lead the prospective investor to invest. Thus, strong bonding with the investor also needed for making them loyal.

\section{ACKNOWLEDGEMENT}

The authors acknowledge the Directorate General of Higher Education, Ministry of Research, Technology, and Higher Education, Republic of Indonesia for financial support of this study through Penelitian Dosen Pemula (PDP) under contract number 071/SP2H/LT/MONO/L7/2019.

\section{REFERENCES}

Anggita T. 2013. Dukungan Modal sosial dalam kolektivitas usaha tani untuk mendukung kinerja produksi pertanian studi kasus: Kabupaten Karawang dan Subang. Journal of Regional and City Planning 24(3): 203-26. https://doi. org/10.5614/jpwk.2013.24.3.4.

Ardiansyah T 2019. Model financial dan teknologi (fintech) membantu permasalahan modal wirausaha UMKM Di Indonesia. Majalah Ilmiah Bijak 16(2): 158-66. https://doi.org/10.31334/ bijak.v16i2.518.

Avisha A et al. 2019. Crowdfunding sebagai akses alternatif permodalan berbasis teknologi digital pada kegiatan pertanain (studi kasus Di PT Crowde Membangun Bangsa). Mimbar Agribisnis 5(1): 1-22. https://doi.org/10.25157/ ma.v5i1.1571.

Baskoro A et al. 2017. Optimalisasi zakat produktif: pengembangan pembiayaan syariah dalam 
pengentasan permodalam pertanian di Indonesia. Restorasi Hukum Jurnal Pusat Studi dan Konsultasi Hukum (PSKH) 2(2): 293-312.

BPS. 2018. Penduduk 15 Tahun Ke Atas Menurut Status Pekerjaan Utama 1986 - 2018. https://www.bps. go.id/statictable/2009/04/16/971/penduduk-15tahun-ke-atas-menurut-status-pekerjaan-utama1986---2018.html.

Chairunisa. 2018. Pengetahuan, kepercayaan, informasi dan teknologi yang mempengaruhi motivasi masyarkat dalam investasi menggunakan crowdfunding syariah. Universitas Islam Syarif Hidayatullah.

Filimonova NG, Ozerova MG, Ermakova IN. 2018. Distinctions of the crowdfunding model in agriculture. Digest Finance 23(1): 98-107. https://doi.org/10.24891/df.23.1.98.

Kusumah H, Mustafa U. 2018. Efektifitas pembiayaan modal usaha oleh baitul mal aceh terhadap usaha agribisnis. Jurnal Bisnis Tani 4(1): 9-25.

LukkarinenAetal.2016. Success drivers ofonline equity crowdfunding campaigns. Decision Support System 87: 26-28.https://doi.org/10.1016/j. dss.2016.04.006.

Mufli M. 2017. Tanimadani.Com: rancang bangun model bisnis islamic financial technology berbasis crowdfunding pembiayaan usaha mikro sektor pertanian. Jurnal Nisbah 3(1): 300-314. https://doi.org/10.30997/jn.v3i1.780.

Rahmawati NA, Arif IS, Arief R. 2018. Factors influencing the purchase intention in online organic fruit and vegetables stores. Jurnal Manajemen \& Agribisnis 15(3): 209-220. https://doi.org/10.17358/jma.15.3.209.

Rofiqi A et al. 2018. Peran bisnis pertanian dalam perekonomian Indonesia. OSF Preprints. https://econpapers.repec.org/scripts/redir. pf?u=https $\% 3 \mathrm{~A} \% 2 \mathrm{~F} \% 2 \mathrm{Fosf} .10 \% 2 \mathrm{Fdownload} \%$ 2F5a7dbccea373f9000dfd4eb2\%2F;h=repec:osf :osfxxx:4vskq.

Saiti B, Muhibullah A, Nazrul HN. 2018. Financing agricultural activities in Afghanistan: A proposed salam-based crowdfunding structure. ISRA International Journal of Islamic Finance 10(1):
52-61.https://doi.org/10.1108/IJIF-09-20170029.

Serfiyani CY. 2018. Karakteristik sistem crowdfunding sebagai alternatif pendanaan industri kreatif. Airlangga University. http://repository.unair. ac.id/74895/.

Supanggih, Dhianon, Slamet W. 2013. Aksesibitas petani terhadap lembaga keuangan (studi kasus pada petani di Desa Sidodadi Kecamatan Sukosewu Kabupaten Bojonegoro). Jurnal Agriekonomika 2(2): 163-73.

Syuaib MF. 2016. Sustainable agriculture in Indonesia: facts and challenges to keep growing in harmony with environment. Agriculture Engineering International 18(2): 170-84.

Tutuko B et al. 2019. Mudharabah agri-crowdfunding in the ex-clay mine utiliation program of $\mathrm{Pt}$. Semen Indonesia (Persero), Tbk. Campus of C Universitas Internasional Semen Indonesia. al-Uqud: Journal of Islamic Economics 3(2): 133-148.https://doi.org/10.26740/al-uqud.v3n2. p133-148.

Vulkan N, Thomas Å, Manuel F. 2016. Journal of business venturing insights equity crowdfunding : a new phenomena. Journal of Business Venturing Insight 5: 37-49. https://doi.org/10.1016/j. jbvi.2016.02.001.

Wati, Cicik R, Agung W. 2018. The performance of crowdfunding model as an alternative funding source for micro, small, and medium-scale businesses in various countries. In KnE Social Sciences 3(3): 16-33. https://doi.org/10.18502/ kss.v3i3.1871.

Winarso B. 2015. Keberhasilan pengembangan ternak sapi potong melalui pola pengembangan modal usaha. Jurnal Penenlitian Petanian Terapan 15(2): 138-50. https://doi.org/10.25181/jppt. v15i2.121.

Yan Z et al. 2018. Agricultural internet entrepreneurs' social network behaviors and entrepreneurship financing performance. Sustainability (Switzerland) 10(8): 1-17. https://doi. org/10.3390/su10082677. 